\title{
Does Tax, Financial, and Government Incentives Impact Long-Term Portuguese SMEs' Sustainable Company Performance?
}

\author{
Sara Picas ${ }^{1}$, Pedro Reis ${ }^{2}$, António Pinto ${ }^{2}$ and José Luís Abrantes ${ }^{2, *(D)}$ \\ 1 Polytechnic Institute of Viseu, 3504-510 Viseu, Portugal; sara28picas@gmail.com \\ 2 CISeD—Research Center in Digital Services, Polytechnic Institute of Viseu, 3504-510 Viseu, Portugal; \\ pedroreis@estv.ipv.pt (P.R.); spinto@estgv.ipv.pt (A.P.) \\ * Correspondence: jlabrantes@estgv.ipv.pt
}

Citation: Picas, S.; Reis, P.; Pinto, A.; Abrantes, J.L. Does Tax, Financial, and Government Incentives Impact Long-Term Portuguese SMEs' Sustainable Company Performance? Sustainability 2021, 13, 11866. https://doi.org/10.3390/su132111866

Academic Editor: Colin Michael Hall

Received: 13 September 2021

Accepted: 20 October 2021

Published: 27 October 2021

Publisher's Note: MDPI stays neutral with regard to jurisdictional claims in published maps and institutional affiliations.

Copyright: (c) 2021 by the authors. Licensee MDPI, Basel, Switzerland. This article is an open access article distributed under the terms and conditions of the Creative Commons Attribution (CC BY) license (https:/ / creativecommons.org/licenses/by/ $4.0 /)$.

\begin{abstract}
This article aims to assess how fiscal and financial incentives and government support conditioned the profitability of Portuguese SMEs between 2010 and 2019. The high tax and financial burdens on SMEs have consequences for sustainability and business development. Thus, the study analyzes different incentives provided by the Portuguese government to ease this burden and improve business profitability. The study uses panel data with fixed effects using five different sources of information from five internal tax grant types, three different European Union program financial subventions, and three national budget-specific expenses. The results obtained suggest that tax incentives influence the profitability of SMEs; however, government incentives do not have any impact. The QREN (financial) incentives positively decide the ROA and negatively impact the ROE, contributing to sustainable performance. Portugal 2020 incentives have a weak effect on the first years, improving in the following years. However, the incentive related to R\&D is not relevant. This work aims to contribute to decision making for managers, shareholders, and government entities, allowing them to choose those measures that could increase the company's added value, and for governments, as a tool to select incentives that will most benefit SMEs" profitability. This work identifies the key incentives that impact companies' profitability.
\end{abstract}

Keywords: tax incentives; financial incentives; grants; profitability; government incentives; ROA; SMEs

\section{Introduction}

Tax and financial incentives and government support assume a growing importance in the development of SMEs, particularly in terms of profitability [1,2]. Government incentives play an essential role in implementing CSR (corporate social responsibility), contributing to the change of the business paradigm, essentially focused on profitability, to a broader perspective that includes three distinct dimensions: profitability, environment, and society [3]. Financial incentives play a significant role in the performance of European companies, allowing an increase in profitability and value [1]. The main objective of government financial incentives is to condition the companies' strategic behavior. Governments can positively or negatively influence business conduct by resorting to incentive policies or deterrent measures [2].

Some studies analyze the theme as a partial approach [4-6], others as an individual inequality impact (see [7]) on the effect of the tax burden on personal income disparity.

This work uses explanatory variables that cover all the tax and financial incentives applied to SMEs in Portugal during the study period. This scope is similar to the one applied by Ravšelj and Aristovnik [3]; however, these authors study several countries and only R\&D incentives. As far as we know, there is not a study that aggregates all the different grant measures in a single study. Furthermore, there remains a scarcity of works dealing with those issues, mainly for SMEs and the Portuguese framework. 
Incentive systems can reduce the costs and risks associated with R\&D (Research and Development) activities, generate financial leverage, and stimulate private investment in basic research [8]. However, some studies $[9,10]$ report a negative or limited effect [11] of grants in R\&D.

Profitability is one of the main concerns in the entire business management process, and its study started in the late 1970s with the identification of its main determinants [12]. Different indicators, namely the Price Earnings Ratio [13], the market value [14], and financial indices [15], could measure profitability.

This theme is not recent. Reis and Augusto [16] identify a set of variables that affect the profitability of listed companies, namely earnings per share [17], dividend per share [18], and interest rate $[19,20]$, among others. The authors also identify different profitability inducers, which will be the object of our study, such as inflation [20,21] and GDP (Gross Domestic Product) growth [22]. In parallel, Serrasqueiro [23] reports on a set of variables that determine the profitability of Portuguese companies not listed on the stock exchange, such as business growth, size, financial leverage, and liquidity.

Magnan and St-Onge [24] idea that group incentives determine sustainable company performance needs additional research. The relationship between sustainability practices and financial performance needs further research, namely in identifying indicators that assess sustainable development [25]. This manuscript intends to answer to the gap verified by former studies.

Considering the lack of a global study that addresses the effect of tax, financial, and government incentives for SMEs in a small economy, this study aims to analyze those variables in the business performance of Portuguese SMEs over a long period (2010 to 2019). The task presented some difficulties, namely in terms of independent variables. Not all SMEs benefited from the same incentive systems, resulting in the absence of values for some companies/years.

The remainder of the paper is as follows: the second section summarizes the literature review on the variables that can explain business profitability, the third states the materials and methods, the fourth states the results, and the fifth states the conclusions.

\section{Literature Review}

\subsection{Profitability}

The concept of profitability, widely used in finance, is associated with the success of an investment. Profitability is related to the ability of companies to generate income higher than exploration and financing expenses, that is, to the concept of evaluating business efficiency $[12,26,27]$, associating the idea of profitability with the ability to generate results.

Profitability indicators help managers and investors provide information on the economic and financial situation experienced by the company in a given period, compare the evolution of the business, and compare the data obtained over a long period. The indicators most used in the literature are Return on Assets (ROA) [26,28], Return on Equity (ROE) [12,29], Return on Sales (ROS) [26], Asset Rotation (AR), Gross Margin (GM) ratio [4,30], and Economic Value Added (EVA) [29].

Profitability indicators, however, have some limitations. Financial quantities are essential to understanding the company's short-term performance; however, they do not reflect the medium and long-term objectives. On the other hand, economic and financial information can be manipulated and altered and can contain errors, leading to indicators that do not reflect an authentic image [31].

This study emphasizes the following profitability drivers: tax incentives and financial incentives from government measures. As control variables, macroeconomic indicators are also considered.

\subsection{Tax Incentives}

The Portuguese government in recent years has been creating numerous initiatives that stimulate competitiveness and business growth through the provision of a set of 
incentive systems. Guerra [32] states that tax benefits allow companies to bear a lower tax burden, increasing profitability. At the level of tax incentive systems, the following variables are considered: the Tax Incentive System in R\&D II (SIFIDE II), the tax benefit for the creation of jobs, the Investment Support Tax Regime (RFAI) for general investment, the Tax Reduction System for SMEs, and the Deduction for Retained and Reinvested Profits (DLRR).

The System of Tax Incentives for Research and Development (SIFIDE) was created in 1997, replaced in 2011 by SIFIDE II, and has remained. Its objective is to recover part of the investment made in research and development $(R \& D)$ and is considered the most crucial incentive for carrying out R\&D activities. In 2002, the R\&D expenditure of Portuguese companies was $31.54 \%$. Huang and Hou [33] assessed the relationship between the profitability of Taiwanese companies and investment in R\&D between 2000 and 2015 and identify a positive relationship. Makeeva et al. [34], in turn, evaluated the influence of taxation on business performance under different $R \& D$ tax incentive programs between 2007 and 2016 and found that companies show an increase in profitability when investing in R\&D.

The tax benefit for creating jobs aims to promote employment for people under 30 years of age. This incentive has generated, since its implementation, a substantial controversy in the Portuguese tax system due to the lack of clarity and because it covers a small number of companies. Despite the improvements introduced, it was revoked in 2018. Cerqua and Pellegrini [35] showed through studies on Italian companies that the impact of employment subsidies on productivity is practically nil.

Another tax benefit to support companies is the Investment Support Tax Regime (RFAI), which allows companies to deduct a percentage of the investment made in noncurrent assets. Praça [36], in work on the determinants of the effective tax rate in Portuguese companies between 2012 and 2016, found that RFAI has a positive impact on profitability.

Between 2008 and 2012, to dynamize and develop the interior areas of the country, the SME Taxation Reduction System was created by the government, revoked in 2012, and reintroduced in 2017. Mills and Newberry [37] state that reducing the tax burden allows companies to obtain higher profitability and become more competitive.

Another tax benefit that encourages companies to reduce taxation stems from the Deduction for Retained and Reinvested Profits (DLRR), a regime that allows the deduction of retained earnings to be reinvested. Carvalho [38] studies the main changes that have taken place in the legislation of micro and small companies since 2003. That research concludes that the firm's mortality is due to the absence of a tax plan that allows for a less demanding taxation system, providing companies with greater profitability. In consequence, the next hypothesis is formulated:

\section{Hypothesis 1 (H1). The tax incentives influence the company profitability.}

\subsection{Financial Incentives}

In terms of Financial Incentives, it is worth mentioning the National Strategic Reference Framework (QREN), which was in force between 2007 and 2013, later replaced by the Portugal 2020 program (PT 2020) for the years 2014 to 2020.

In mid-2007, numerous structural difficulties prevailed in Portugal, marked by low levels of competitiveness and productivity, leading to a reduction in the growth of the Portuguese economy. The QREN allowed us to reverse this trend, placing Portugal on a convergence path with the other European countries. This incentive was based on three sub-incentive systems: The Incentive System for Research and Technological Development of Companies, the Innovation Incentive System, and the Incentive System for Qualification and Internationalization of SMEs. Carvalho [4], in a study carried out on the impact of subsidies (SI Inovação) on the gross margin of companies, did not identify any influence. Monteiro [39] states that the QREN incentives did not have the desired effects, given 
the impact of the economic and financial crisis that Portugal was experiencing during its implementation.

Portugal 2020 replaces the QREN and integrates community support for investment and funding priorities essential to promoting innovative and sustainable growth. Portugal 2020 was based on three sub-incentives: the Incentive System for Research and Technological Development, the Incentive System for Qualification and Internationalization of SMEs, and the Incentive System for Business Innovation and Entrepreneurship. These sub-incentives are a mirror of the QREN sub-incentives and thus comparable for our analysis. Monteiro [39], in a study on the internationalization of SMEs in the information and communication technology sector candidates for Portugal 2020, refers to the relevance of these incentives for the country's development. Accordingly, the following hypothesis is conveyed:

Hypothesis 2 (H2). The financial incentives influence the company profitability through a lagged effect.

\subsection{Government Expenses}

At the level of Government Support, it is crucial to assess the effect of Health Expenses, Education Expenses, and the establishment of the Minimum Wage on the profitability of SMEs. Despite the improvements seen in health expenditures over the past few years, the goal set by different governments is far from being achieved [40]. The scientific publication Lancet [41] —one of the most prestigious medical journals in the world — published an editorial that refers to the great improvements of the Portuguese National Health Service in the last 40 years. The magazine exemplifies infant mortality in the positive indicators that fell from 3.3 per 1000 live births in 2006 to 2.9 in 2017. Health expenditures have shown irregular behavior over the last few years, with values ranging between $€ 8000$ million and $€ 10,000$ million. Baganha et al. [5] found that companies must ensure that workers are healthy and motivated, ensuring better productivity and profitability for companies to produce with high performance.

Education appears as a right enshrined in the constitution of a very significant number of countries. In Portugal, the education system seeks to promote equal opportunities and conditions of access for all individuals. State spending on education has registered a slight increase in recent years, reaching between $€ 6000$ million and $€ 8000$ million; however, the numbers are lower than they were ten years ago. Jaya et al. [42] assess the impact of training on business profitability and identify a positive relationship between them.

In Portugal, the minimum wage was created in 1974 to raise the lowest wages after Portugal's April 25 revolution. In recent years, its value has been increasing, reaching $€ 600$ per worker in 2019. Draca et al. [43], in a study carried out on the minimum wage introduced in the United Kingdom in 1999, found that the increases observed significantly reduce business profitability. As per the literature reviewed, the next hypothesis is established:

\section{Hypothesis 3 (H3). Government expenses influence company profitability.}

Macroeconomic magnitudes are one of the main concerns of managers and entrepreneurs insofar as they affect business activity. In this context, the Gross Domestic Product (GDP), the Inflation Rate, and the Level of Unemployment are relevant.

The Gross Domestic Product (GDP), one of the main macroeconomic variables, has an irregular growth rate in the Portuguese context in recent years. Between 2010 and 2012, there was a sharp decrease in the GDP growth rate. From 2012 onwards, there has been a considerable increase, with a slight reduction in 2017 (PORTDATA, 2020). Antunes [6], in work on the impact of macroeconomic variables on the performance of SMEs between 2003 and 2013, finds that GDP growth encourages economic activity and greater profitability of SMEs.

The inflation rate is often associated with boom or bust cycles and the evolution of operating expenses, making business results more volatile. As with GDP, the inflation rate 
has shown an undefined development over the last ten years. Between 2010 and 2011, there was an increase; however, in 2012, the inflation rate decreased and remained at that value until 2014. From 2015, it increased again until 2018, when it decreased further. Osoro and Ogeto [44] report that the rise in the inflation rate harms corporate profitability.

The unemployment rate is another crucial variable for business profitability. Over the past ten years, the unemployment rate has fluctuated between $6.5 \%$ and $16.2 \%$ (PORTDATA, 2020). Varela and Pereira [45], in a study on the workforce composition in Europe and Mucharreira, report that the increase in unemployment in an analysis of Portuguese SMEs between the 2003 and 2013 rates positively affects business profitability.

\section{Materials and Methods}

Our data arise from five different databases that we joined through a common denominator-the tax identification number. The Portuguese companies that benefited from tax incentives, such as the Tax Incentive System for Business R\&D II, the Job Creation Investment Support Tax Regime (RFAI), the Deduction of Retained and Reinvested Profits (DLRR), and the Interiority incentives, are in the Internal Revenue Service of Portugal. Those funds come from the Portuguese State budget. The EU budget finances the financial incentives. The extensive time frame of the analysis (2010 to 2019) implies the existence of different EU programs for similar support measures: the QREN (Quadro de Referência Estratégico Nacional) and the Portugal 2020. These include the Incentive to Technological R\&D-QREN, replaced by the Business R\&D Incentive System-PT2020; the Incentive to Innovation-QREN, replaced by the Business Innovation Incentive System-PT2020; and the Incentive to Qualification and Internationalization-QREN, replaced by the Business Qualification Incentive System-PT2020. Companies that benefited from these programs during those years must have the respective information on the program sites. Government expense measures, such as health expenses, education expenses, minimum wage, and macro variables, such as Gross Domestic Product, Inflation Rate, and Unemployment rate, are retrieved from the PORDATA database, a free database created by Fundação Francisco Manuel dos Santos (FFMS). Finally, to obtain financial performance measures, return on assets (ROA) and return on equity (ROE), we referred to the SABI database (Iberian Balance Analysis System) using the tax identification number as a standard indicator.

In Portugal, in 2018, there were 1,295,299 companies, of which 99.9\% were micro, small, and medium-sized companies (SMEs) [46].

The final database was selected from a group of Portuguese SMEs, for the period 2010 to 2019, which benefited from tax incentives (source of data: www.portaldasfinanças.gov.pt (accessed on 29 January 2021)), financial incentives (obtained in www.qren.pt (accessed on 29 January 2021) and www.compete2020.gov.pt (accessed on 29 January 2021)), government support, and macro control variables (retrieved from www.pordata.pt (accessed on 29 January 2021)). The databases include all companies that benefited from at least one type of incentive between 2010 and 2019. Companies' financial information of profitability was also included and matched by personal tax identification numbers. The time horizon 2010-2019 was selected because it is the maximum period available in the databases, it is a recent period, and it is a broad period that can capture changes in trends.

Financial variables were obtained for all Portuguese companies through the SABI database (Iberian Balance Analysis System) that have information on ROA and ROE, allowing the construction of a sample of 397,892 SMEs (year, company) on activity. This work uses explanatory variables that cover all the tax and financial incentives applied to SMEs in Portugal during the period. This scope is similar to the one applied by Ravšelj and Aristovnik [3]; however, these authors study several countries and only R\&D incentives.

Multiple linear regressions with static panel data are used, and the Hausman specification test is applied to assess whether the correlation between Eit (error term) and X (independent variable) validates the null hypothesis (H0)-random effects (RE) (Hausman, 1978). The test results indicate that Prob $>\mathrm{Chi}^{2}$ are significant, so the alternative specification is used, that is, fixed effects (FE). 
Table 1 presents a summary description of all the measures used in the study, as well as the expression that allows us to determine their value.

The panel data regression model has the following generic specification:

$$
Y_{i t}=\beta_{0}+\beta_{1} X_{i t}+\beta_{2} G D P P_{i t}+\beta_{3} \text { Inflation Rate }_{i t}+\beta_{4} \text { Unemployment }_{i t}+E_{i t}
$$

where $\mathrm{Y}$ represents the dependent variable, ROE or ROA; $\mathrm{X}$ represents the tax incentives (SIFIDE II, Job Creation, Investment Support, DLRR, RFAI, Interiority), financial incentives of QREN, Portugal 2020, Government Expenditures (health expenditures, education, and minimum wage); and $\mathrm{E}_{\mathrm{it}}$ represents the error term.

Finally, to assess the presence of heteroscedasticity, the White test is used. The original model is used to correct heteroscedasticity and the estimation with robust standard errors.

Table 1. Summary of select variables and their operationalization.

\begin{tabular}{|c|c|c|c|c|c|c|}
\hline $\begin{array}{l}\text { Variable } \\
\text { Type }\end{array}$ & Dep./Indep. & Variable Name & Measure & Designation & Expression & Source of Data \\
\hline \multirow{2}{*}{ Profitability } & Dependent & ROA & $\%$ & Return on Asset & Operating Income/Assets & SABI database \\
\hline & Dependent & ROE & $\%$ & Return on Equity & Net Income/Equity & SABI database \\
\hline \multirow{5}{*}{$\begin{array}{c}\text { Tax } \\
\text { Incentives }\end{array}$} & Independent & SIFIDE II & $€$ & $\begin{array}{l}\text { Tax Incentive } \\
\text { System for Business } \\
\text { R\&D II }\end{array}$ & SIFIDE Tax Incentive & \multirow{5}{*}{$\begin{array}{l}\text { https://info.portaldasfinancas.gov.pt/ } \\
\text { pt/dgci/divulgacao/Area_Beneficios_ } \\
\text { Fiscais/Listas_de_contribuintes_com_ } \\
\text { beneficios_fiscais/Paginas/ } \\
\text { Contribuintes_com_beneficios_fiscais_ } \\
\text { 2020.aspx (accessed on 29 January } \\
\text { 2021) }\end{array}$} \\
\hline & Independent & Creating jobs & $€$ & Job Creation & Job Creation Tax Incentive & \\
\hline & Independent & Support invest. & $€$ & $\begin{array}{l}\text { Investment Support } \\
\text { Tax Regime (RFAI) }\end{array}$ & RFAI Tax Incentive & \\
\hline & Independent & $\begin{array}{l}\text { Retained } \\
\text { earnings } \\
\text { deduction }\end{array}$ & $€$ & $\begin{array}{l}\text { Deduction of } \\
\text { Retained and } \\
\text { Reinvested Profits } \\
\text { (DLRR) }\end{array}$ & DLRR Tax Incentive & \\
\hline & Independent & Interiority & $€$ & Interiority & Interiority Tax Incentive & \\
\hline \multirow{6}{*}{$\begin{array}{l}\text { Financial } \\
\text { Incentive }\end{array}$} & Independent & Incentive Type 1 & $€$ & $\begin{array}{l}\text { Incentive to } \\
\text { Technological } \\
\text { R\&D—QREN }\end{array}$ & $\begin{array}{l}\text { Financial Incentive for } \\
\text { Technological R\&D }\end{array}$ & \multirow{3}{*}{$\begin{array}{c}\text { http:/ / www.pofc.qren.pt/Areas-do- } \\
\text { Compete/Incentivos-as-Empresas / } \\
\text { Projectos-Aprovados-QREN?area=2\& } \\
\text { regiao=102\&Search=y (accessed on } 29 \\
\text { January 2021) }\end{array}$} \\
\hline & Independent & Incentive Type 2 & $€$ & $\begin{array}{c}\text { Incentive to } \\
\text { Innovation-QREN }\end{array}$ & $\begin{array}{l}\text { Financial Incentive for } \\
\text { Innovation }\end{array}$ & \\
\hline & Independent & Incentive Type 3 & $€$ & $\begin{array}{l}\text { Incentive to } \\
\text { Qualification and } \\
\text { Internationalization- } \\
\text { QREN }\end{array}$ & $\begin{array}{l}\text { Financial Incentive for } \\
\text { Qualification and } \\
\text { Internationalization }\end{array}$ & \\
\hline & Independent & Incentive Type 4 & $€$ & $\begin{array}{l}\text { Business R\&D } \\
\text { Incentive } \\
\text { System-PT2020 }\end{array}$ & $\begin{array}{l}\text { Financial Incentive for } \\
\text { Business R\&D }\end{array}$ & \multirow{3}{*}{$\begin{array}{c}\text { https: / / www.compete2020.gov.pt/ } \\
\text { Projetos/Projetos (accessed on } 29 \\
\text { January 2021) }\end{array}$} \\
\hline & Independent & Incentive Type 5 & $€$ & $\begin{array}{l}\text { Business } \\
\text { Qualification } \\
\text { Incentive } \\
\text { System-PT2020 }\end{array}$ & $\begin{array}{l}\text { Financial Incentive for } \\
\text { Business Qualification }\end{array}$ & \\
\hline & Independent & Incentive Type 6 & $€$ & $\begin{array}{l}\text { Business Innovation } \\
\text { Incentive } \\
\text { System-PT2020 }\end{array}$ & $\begin{array}{l}\text { Financial Incentive for } \\
\text { Business Innovation }\end{array}$ & \\
\hline \multirow{3}{*}{$\begin{array}{l}\text { Governmental } \\
\text { Support }\end{array}$} & Independent & Health & $M €$ & Health expense & $\begin{array}{l}\text { State Expenditure on } \\
\text { Health }\end{array}$ & $\begin{array}{l}\text { www.pordata.pt (accessed on } 29 \\
\text { January 2021) }\end{array}$ \\
\hline & Independent & Education & $M €$ & Education expense & $\begin{array}{l}\text { State Expenditure on } \\
\text { Education }\end{array}$ & $\begin{array}{l}\text { www.pordata.pt (accessed on } 29 \\
\text { January 2021) }\end{array}$ \\
\hline & Independent & Salary Min. & $€$ & Minimum wage & $\begin{array}{l}\text { Minimum Wage in } \\
\text { Portugal }\end{array}$ & $\begin{array}{l}\text { www.pordata.pt (accessed on } 29 \\
\text { January 2021) }\end{array}$ \\
\hline \multirow{3}{*}{$\begin{array}{l}\text { Macro } \\
\text { (Control } \\
\text { variables) }\end{array}$} & Independent & GDP & $\%$ & $\begin{array}{l}\text { Gross Domestic } \\
\text { Product }\end{array}$ & $\begin{array}{l}\text { Private consumption }+ \\
\text { investment + public } \\
\text { spending }+ \text { exports - } \\
\text { imports }\end{array}$ & $\begin{array}{l}\text { www.pordata.pt (accessed on } 29 \\
\text { January 2021) }\end{array}$ \\
\hline & Independent & Inflation rate & $\%$ & $\begin{array}{l}\text { Inflation Rate }(\mathrm{P} \\
\text { price level) }\end{array}$ & $(\mathrm{P}-\mathrm{Pt}-1) / \mathrm{Pt}-1$ & $\begin{array}{l}\text { www.pordata.pt (accessed on } 29 \\
\text { January 2021) }\end{array}$ \\
\hline & Independent & Unemployment & $\%$ & Unemployment rate & $\begin{array}{l}\text { Number of } \\
\text { Unemployed/Active } \\
\text { Population }\end{array}$ & $\begin{array}{l}\text { www.pordata.pt (accessed on } 29 \\
\text { January 2021) }\end{array}$ \\
\hline
\end{tabular}




\section{Results}

This section will present the descriptive statistics and the estimation results for each type of subvention grouped by tax, financial, and government incentives. This work will carry on a lagged estimation for the financial incentives that may have a delayed impact on performance.

Based on the sample, consisting of 397,892 Portuguese SMEs (year, firm) and for the period from 2010 to 2019, it was possible to draw up Table 2, which gives an account of the descriptive statistics of the dependent and independent variables. Macroeconomic quantities appear as control variables.

Table 2. Descriptive statistics.

\begin{tabular}{cccccc}
\hline Type & Variable & Mean & Stand. Dev. & Minimum & Maximum \\
\hline \multirow{2}{*}{ Dependent } & ROA (\%) & -43.34 & 24,321 & $-14,906,625$ & $1,303,940$ \\
\cline { 2 - 6 } & ROE $(\%)$ & 10.64 & 6074 & $-1,636,017$ & $3,014,414$ \\
\hline \multirow{5}{*}{ Fiscal } & SIFIDE II $(€)$ & 1749 & 47,194 & 0 & $11,497,894$ \\
\cline { 2 - 6 } & Job creation $(€)$ & 736 & 11,447 & 0 & $2,860,012$ \\
\cline { 2 - 6 } & Support invest. $(€)$ & 1731 & 44,953 & 0 & $9,640,870$ \\
\cline { 2 - 6 } & Retained earning $(€)$ & 684 & 6075 & 0 & 370,000 \\
\cline { 2 - 6 } & Interiority $(€)$ & 423 & 5111 & 0 & 594,511 \\
\hline \multirow{3}{*}{ Governmental } & Health $(\mathrm{M} €)$ & 9039 & 626 & 8332 & 10,403 \\
\cline { 2 - 6 } & Education $(\mathrm{M} €)$ & 7200 & 586 & 6622 & 8559 \\
\cline { 2 - 6 } & Salary Mín. $(€)$ & 516 & 43 & 475 & 600 \\
\hline \multirow{3}{*}{ Macro } & GDP $(\%)$ & 0.79 & 2.21 & -4.06 & 3.51 \\
\cline { 2 - 6 } & Inflation rate $(\%)$ & 1.17 & 1.17 & -0.3 & 3.7 \\
\cline { 2 - 6 } & Unemployment $(\%)$ & 11.42 & 3.22 & 6.5 & 16.2 \\
\hline
\end{tabular}

Note: own elaboration.

Table 3 shows the result of the estimation, bearing in mind the set of tax incentives.

Table 3. Tax Incentives.

\begin{tabular}{ccccc}
\hline & \multicolumn{2}{c}{ ROA } & ROE \\
\hline & Coefficient & $p$-Value & Coefficient & $p$-Value \\
\hline Log SIFIDE II & 2.81801 & 0.000 & 12.96399 & 0.030 \\
\hline GDB & 46.88339 & 0.000 & 624.7633 & 0.209 \\
\hline Inflation rate & 36.80227 & 0.029 & 638.2626 & 0.249 \\
\hline Unemployment rate & 40.62391 & 0.000 & 477.6394 & 0.155 \\
\hline Log Creating jobs & 0.3211466 & 0.039 & 0.680057 & 0.759 \\
\hline GDB & 52.89569 & 0.000 & 428.5165 & 0.026 \\
\hline Inflation rate & 34.43015 & 0.003 & 413.6364 & 0.001 \\
\hline Unemployment rate & 35.96722 & 0.000 & 314.4091 & 0.006 \\
\hline Log Support Invest & 2.475172 & 0.000 & 4.755648 & 0.000 \\
\hline GDB & 31.07681 & 0.000 & 414.272 & 0.055 \\
\hline Inflation rate & 38.81551 & 0.000 & 534.5211 & 0.057 \\
\hline Unemployment rate & 47.49908 & 0.000 & 307.594 & 0.000 \\
\hline
\end{tabular}


Table 3. Cont.

\begin{tabular}{ccccc}
\hline & \multicolumn{2}{c}{ ROA } & \multicolumn{2}{c}{ ROE } \\
\hline & Coefficient & $p$-Value & Coefficient & $p$-Value \\
\hline Log Retained earning & 3.738798 & 0.000 & 7.010055 & 0.000 \\
\hline GDB & 110.9765 & 0.001 & 309.4962 & 0.519 \\
\hline Inflation rate & 14.56867 & 0.803 & 54.57968 & 0.950 \\
\hline Unemployment rate & 82.12837 & 0.000 & 275.5407 & 0.000 \\
\hline Log Interiority & 4.689406 & 0.000 & 16.42452 & 0.002 \\
\hline GDB & -10.07938 & 0.763 & 126.3903 & 0.540 \\
\hline Inflation rate & 59.47596 & 0.253 & 122.4777 & 0.702 \\
\hline Unemployment rate & -201.0915 & 0.000 & -455.5427 & 0.035 \\
\hline
\end{tabular}

Note: own elaboration.

A first analysis presents a set of tax variables. SIFIDE II proves to be significant in ROA and ROE. According to the conclusions of Reis and Augusto [16], this tax benefit enhances the company's future operating performance and determines shareholder profitability through lower taxation. The small number of studies carried out on Portuguese companies, the specificity of their context, and the nature of the incentive systems, specifically the tax incentives, complicates the comparison of results. However, the findings are in line with Mayende's [47] work on R\&D tax incentive programs and corporate taxation, referring to a positive impact on profitability. Makeeva et al. [34] assess the impact of tax incentives on $R \& D$ and find an increase in profitability.

The following variable to analyze is the tax benefit associated with job creation, revealing statistical significance in ROA. The $\mathrm{p}$ value of "log-creating jobs" is significant for an alpha $=5 \%$ value according to Table 3 on ROA in our sample of Portuguese companies for the analyzed period, which suggests that it could be leverage for hiring qualified people.

This result can also be explained by the fact that this benefit significantly impacts the company's operational activity, affecting the admission of new workers and enhancing the creation of value. The results do not validate the conclusions of Cerqua and Pellegrini [35], who state that subsidies associated with job creation in Italian companies did not affect operational profitability. Another variable with statistical significance is the Investment Support Tax Regime (RFAI). These results are in line with Praça [36]. A survey carried out on the determinants of the effective tax rate in companies in Portugal between 2012 and 2016 concluded that RFAI has a positive impact on ROA.

Another significant variable is the DLRR, which is related to the tax incentive associated with self-financing, namely the retention of profits for investment, allowing the results to conclude that they favorably affect the performance of companies. Finally, the tax benefit to interiority positively conditions ROA and ROE.

Table 4 shows the results of the estimation, bearing in mind the set of QREN financial incentives: Incentive System for Research and Technological Development (SI I\&DT), Innovation Incentive System (SI I), and SME Qualification and Internationalization Incentive System (SI Q\&I).

The first financial incentive under analysis, the SI I\&DT, according to Table 5, exposes the significant relevance only in ROA. This result is in line with the findings of Mateus et al. [48], when they mention that the incentive to R\&DT works as an amplifier, allowing companies to invest more aggressively, allowing higher operational profitability. Another incentive, SI I, conditions ROA positively and ROE negatively. The positive impact on ROA comes from the creation of new processes and products associated with this incentive. The effect on negative ROE arises from the fact that this type of incentive, in the non-refundable part, is classified as equity equivalents under the Portuguese Accounting Standardization System (SNC). The first stage may lead to a reduction in the profitability ratio. Carvalho [4], in a study carried out on the impact of the subsidy (SI Inovação) on the gross margin of companies, did not identify any relationship; however, he found an improvement in 
profitability. Finally, the SI Q\&I positively conditions the ROA and negatively conditions the ROE. This result can be explained by the economic and financial crisis experienced in Portugal during its implementation, as mentioned by Mateus et al. [48]. The results show that, despite the situation, companies that benefit from this incentive obtain positive effects in terms of operating activity but receive adverse effects on shareholder remuneration. García-Manjón and Romero-Merino [49] studied the effect of granting incentives on companies. They concluded that these affect the development of companies, namely in terms of turnover, results, and job creation, observing a positive relationship between investment in $R \& D$ and the company's growth.

Table 4. Financial incentives (QREN).

\begin{tabular}{ccccc}
\hline & \multicolumn{2}{c}{ ROA } & ROE \\
\hline & Coefficient & $p$-Value & Coefficient & $p$-Value \\
\hline Incentive Type 1 & 0.0045335 & 0.000 & 0.0066119 & 0.198 \\
\hline GDB & -64.81805 & 0.755 & 396.0809 & 0.717 \\
\hline Inflation rate & -200.0374 & 0.407 & -266.5964 & 0.833 \\
\hline Unemployment rate & -173.0272 & 0.365 & -254.3937 & 0.787 \\
\hline Incentive Type 2 & 0.010634 & 0.000 & -0.1680349 & 0.000 \\
\hline GDB & -267.4963 & 0.356 & 1233.258 & 0.481 \\
\hline Inflation rate & -336.2105 & 0.257 & 1609.57 & 0.342 \\
\hline Unemployment rate & -616.4081 & 0.103 & 1418.217 & 0.394 \\
\hline Incentive Type 3 & 0.0309824 & 0.000 & -0.005167 & 0.000 \\
\hline GDB & 958.8517 & 0.269 & 3855.494 & 0.102 \\
\hline Inflation rate & 1338.076 & 0.304 & 4516.002 & 0.103
\end{tabular}

Note: own elaboration; Incentive Type 1-Incentive System for Research and Technological Development (SI I\&DT); Incentive Type 2-Innovation Incentive System (SI I); and Incentive Type 3-SME Qualification and Internationalization Incentive System (SI Q\&I).

Tables 5-7 show the results of the estimation, bearing in mind the set of Portugal 2020 financial incentives: Incentive System for Corporate R\&D (SI R\&D), System of Incentives for Business Qualification and Internationalization (SI Q\&I-PT2020), and System of Incentives for Business Innovation (SI I).

Regarding the financial incentive system, Portugal 2020, the analysis covers five periods to assess the impact during the year of implementation (first year) and throughout the following years (until the fifth year).

Table 5. Financial incentives-Corporate R\&D Incentive System (SI I\&D) (Portugal 2020).

\begin{tabular}{ccccc}
\hline & \multicolumn{2}{c}{ ROA } & ROE \\
\hline & Coefficient & $p$-Value & Coefficient & $p$-Value \\
\hline Incentive Type 4-lag1 & 0.007886 & 0.673 & -0.5534514 & 0.437 \\
\hline GDB & -695.5632 & 0.171 & $57,197.91$ & 0.362 \\
\hline Inflation rate & 849.9612 & 0.191 & $-94,943.22$ & 0.349 \\
\hline Unemployment rate & 44.25326 & 0.484 & $14,302.48$ & 0.325 \\
\hline Incentive Type 4-lag2 & -0.0007053 & 0.981 & 3.435416 & 0.331 \\
\hline GDB & -667.7694 & 0.248 & $70,692.35$ & 0.346 \\
\hline Inflation rate & 776.9617 & 0.29 & $-112,437.3$ & 0.337 \\
\hline Unemployment rate & 43.90611 & 0.554 & $17,752.28$ & 0.32 \\
\hline Incentive Type 4-lag3 & -973.4225 & 0.188 & 9.864708 & 0.251 \\
\hline
\end{tabular}


Table 5. Cont.

\begin{tabular}{ccccc}
\hline & \multicolumn{2}{c}{ ROA } & ROE \\
\hline & Coefficient & $p$-Value & Coefficient & $p$-Value \\
\hline Inflation rate & 36.20777 & 0.105 & $11,536.29$ & 0.294 \\
\hline Unemployment rate & 10.73632 & 0.551 & -358.3731 & 0.635 \\
\hline Incentive Type 4-lag4 & 0.0158458 & 0.113 & $3,326,503$ & 0.393 \\
\hline GDP & -622.3332 & 0.242 & $63,884.55$ & 0.361 \\
\hline Inflation rate & 749.8234 & 0.271 & $-94,197.53$ & 0.345 \\
\hline Unemployment rate & 43.38945 & 0.482 & $14,020.76$ & 0.32 \\
\hline Incentive Type 4-lag5 & -0.0358543 & 0.116 & -13.76783 & 0.249 \\
\hline GDB & -791.6488 & 0.118 & 6217.247 & 0.844 \\
\hline Inflation rate & 867.2617 & 0.184 & $-53,005.71$ & 0.358 \\
\hline
\end{tabular}

Note: Incentive Type 4-Corporate R\&D Incentive System (SI I\&D). Own elaboration.

Table 5 analyzes the influence of the Corporate R\&D Incentive System (SI R\&D) on the profitability of SMEs, and this type of incentive has no impact on profitability, regardless of the time horizon adopted. These results align with Tirole's (2018) [50] when he says that small and medium-sized companies have difficulty improving profitability through projects, mainly in research and development.

Table 6. Financial Incentives-System of Incentives for Business Qualification and Internationalization (SI Q\&I) (Portugal 2020).

\begin{tabular}{|c|c|c|c|c|}
\hline & \multicolumn{2}{|c|}{ ROA } & \multicolumn{2}{|c|}{ ROE } \\
\hline & Coefficient & $p$-Value & Coefficient & $p$-Value \\
\hline Incentive Type 5-lag1 & -0.008907 & 0.000 & -0.1219684 & 0.008 \\
\hline GDB & -629.6172 & 0.000 & -5974.433 & 0.142 \\
\hline Inflation rate & 1128.277 & 0.000 & 5723.521 & 0.045 \\
\hline Unemployment rate & -40.25894 & 0.05 & -315.6482 & 0.17 \\
\hline Incentive Type 5-lag2 & -0.0010273 & 0.000 & 0.0022483 & 0.000 \\
\hline GDB & -566.3604 & 0.000 & -6292.237 & 0.127 \\
\hline Inflation rate & 1018.129 & 0.000 & 6053.119 & 0.036 \\
\hline Unemployment rate & -28.50532 & 0.1 & -337.691 & 0.141 \\
\hline Incentive Type 5-lag3 & 0.0009041 & 0.000 & -0.0008215 & 0.616 \\
\hline GDB & -564.4045 & 0.000 & -6198.604 & 0.133 \\
\hline Inflation rate & 1018.311 & 0.000 & 5904.849 & 0.041 \\
\hline Unemployment rate & -27.03514 & 0.118 & -324.2811 & 0.154 \\
\hline Incentive Type 5-lag4 & 0.0008507 & 0.491 & -0.0076257 & 0.535 \\
\hline GDB & -641.8721 & 0.000 & -6120.465 & 0.14 \\
\hline Inflation rate & 1137.394 & 0.000 & 5768.105 & 0.047 \\
\hline Unemployment rate & -40.08268 & 0.0056 & -311.9785 & 0.181 \\
\hline Incentive Type 5-lag5 & 0.0011206 & 0.000 & -0.0024605 & 0.000 \\
\hline GDB & -558.4421 & 0.000 & -6310.172 & 0.123 \\
\hline Inflation rate & 1007.06 & 0.000 & 6078.273 & 0.035 \\
\hline Unemployment rate & -27.79908 & 0.105 & 339.3264 & 0.139 \\
\hline
\end{tabular}

Note: Incentive Type 5-Incentive System for Qualification and Business Internationalization (SI Q\&I). Own elaboration.

Table 6 reproduces the influence of the Incentive System for Qualification and Business Internationalization (SI Q\&I) on profitability. This incentive negatively affects the ROA in 
the first two years. However, the effect is positive in the third year; it is not significant in the fourth year, but it positively affects the ROA in the fifth year. Considering that these subsidies to internationalization take time to induce profitability, it is expected that in the first two years after the grant is recognized, the impacts of the investment in qualification and internationalization will not be noted yet. In the first years, companies invest in people and fairs and visit countries to open markets without any proceeds from that investment. In the long run, the impact on sales and results is positive. However, this occurrence may be affected by the Portuguese sovereign credit verified from the years 2010 to 2014 [51].

Regarding ROE, it has a negative impact. In the second year, the impact is positive. It has no significance in the third and fourth year, and it presents significance in the fifth year with a negative relationship.

Table 7. Financial Incentives-Incentive System for Business Innovation (SI I) (Portugal 2020).

\begin{tabular}{|c|c|c|c|c|}
\hline & \multicolumn{2}{|c|}{ ROA } & \multicolumn{2}{|c|}{ ROE } \\
\hline & Coefficient & $p$-Value & Coefficient & $p$-Value \\
\hline Incentive Type 6-lag1 & -0.006077 & 0.024 & -0.0030712 & 0.000 \\
\hline GDB & 502.5854 & 0.573 & 1546.981 & 0.534 \\
\hline Inflation rate & -189.2497 & 0.836 & 258.6989 & 0.916 \\
\hline Unemployment rate & 67.51612 & 0.395 & 130.0782 & 0.564 \\
\hline Incentive Type 6-lag2 & -0.0001374 & 0.692 & 0.019719 & 0.037 \\
\hline GDB & 812.9016 & 0.301 & 1587.171 & 0.488 \\
\hline Inflation rate & -645.2878 & 0.486 & -227.5288 & 0.924 \\
\hline Unemployment rate & 99.63398 & 0.140 & 163.2798 & 0.445 \\
\hline Incentive Type 6 - lag3 & 0.0011413 & 0.276 & 0.0054426 & 0.036 \\
\hline GDB & 553.7655 & 0.546 & 1788.694 & 0.486 \\
\hline Inflation rate & -305.3258 & 0.750 & -292.313 & 0.909 \\
\hline Unemployment rate & 85.2309 & 0.316 & 214.7556 & 0.358 \\
\hline Incentive Type 6 - lag4 & 0.000516 & 0.831 & 0.0001755 & 0.987 \\
\hline GDB & 847.5008 & 0.318 & 1497.946 & 0.560 \\
\hline Inflation rate & -698.2633 & 0.487 & 313.1593 & 0.906 \\
\hline Unemployment rate & 104.8305 & 0.149 & 133.5809 & 0.545 \\
\hline Incentive Type 6 - lag5 & 0.0224326 & 0.002 & 0.0819027 & 0.000 \\
\hline GDB & 376.0622 & 0.644 & 1073.503 & 0.622 \\
\hline Inflation rate & -13.46143 & 0.987 & 912.8633 & 0.678 \\
\hline Unemployment rate & 45.16574 & 0.546 & 49.47054 & 0.803 \\
\hline
\end{tabular}

Note: Incentive Type 6-Incentive System for Business Innovation (SI I). Own elaboration.

Finally, the analysis includes the Incentive System for Business Innovation (SI I). The table above reveals that the effect of this incentive on profitability is not consistent over time. The results suggest that these incentives have a long-term impact shown in the fifth period with a positive association with sustainable performance. Bannò et al., (2014) [52], in a study on the impact of investment subsidies on ROA, found that companies that benefit from these incentives showed better performance.

Table 8 assesses the impact of government support to meet different types of expenditure and boost the economy on business profitability. 
Table 8. Government Support.

\begin{tabular}{ccccc}
\hline & \multicolumn{2}{c}{ ROA } & \multicolumn{2}{c}{ ROE } \\
\hline & Coefficient & $p$-Value & Coefficient & $p$-Value \\
\hline Log Health & -1495.397 & 0.289 & -263.966 & 0.520 \\
\hline Log Education & -735.5891 & 0.310 & 262.2182 & 0.037 \\
\hline Log Minimum wage & 483.5324 & 0.666 & -285.155 & 0.337 \\
\hline GDP & 6324.626 & 0.167 & -2329.837 & 0.292 \\
\hline Inflation rate & 1661.208 & 0.757 & -418.2824 & 0.753 \\
\hline Unemployment rate & -2019.504 & 0.454 & -1697.201 & 0.309 \\
\hline Note: own elaboration & & & &
\end{tabular}

Note: own elaboration.

According to Table 8, only spending on education has statistical significance in ROE. An underlying hypothesis of this result stems from the fact that public policies and investing in the training of young people increase qualifications and, therefore, profitability. In turn, Roper and Dundas (2001) [53], in a study of companies in Northern Ireland, conclude that government support designed for companies does not affect business profitability.

Table 9 seeks to summarize the results obtained, bearing in mind the different profitability inducers.

Table 9. Summary of Results Obtained.

\begin{tabular}{|c|c|c|c|}
\hline Incentive & Incentive Type & ROA & ROE \\
\hline \multirow{5}{*}{ Fiscal Incentive } & SIFIDE II & + & + \\
\hline & Job creation-EBF & + & $\mathrm{x}$ \\
\hline & Job creation-RFAI & + & + \\
\hline & DLRR & + & + \\
\hline & Interiority & + & + \\
\hline \multirow{18}{*}{ Financial Incentive } & QREN-Incentive to I\&DT & + & $\mathrm{x}$ \\
\hline & QREN-Incentive to Innovation & + & - \\
\hline & QREN-Incentive to Qualification and Internationalization & + & - \\
\hline & PT2020—Incentive to Business R\&D—lag1 & $\mathrm{x}$ & $\mathrm{x}$ \\
\hline & PT2020-Incentive to Business R\&D—lag2 & $\mathrm{x}$ & $x$ \\
\hline & PT2020-Incentive to Business R\&D—lag3 & $\mathrm{x}$ & $\mathrm{x}$ \\
\hline & PT2020-Incentive to Business R\&D—lag4 & $\mathrm{x}$ & $\mathrm{x}$ \\
\hline & PT2020-Incentive to Business R\&D—lag5 & $\mathrm{x}$ & $\mathrm{x}$ \\
\hline & PT2020-Incentive to Qualification and Internationalization-lag1 & - & - \\
\hline & PT2020-Incentive to Qualification and Internationalization-lag2 & - & + \\
\hline & PT2020-Incentive to Qualification and Internationalization-lag3 & + & $\mathrm{x}$ \\
\hline & PT2020-Incentive to Qualification and Internationalization-lag4 & $\mathrm{x}$ & $\mathrm{x}$ \\
\hline & PT2020-Incentive to Qualification and Internationalization-lag5 & + & - \\
\hline & PT2020-Incentive to Innovation—lag1 & - & - \\
\hline & PT2020-Incentive to Innovation-lag2 & $\mathrm{x}$ & + \\
\hline & PT2020-Incentive to Innovation-lag3 & $\mathrm{x}$ & + \\
\hline & PT2020-Incentive to Innovation-lag4 & $\mathrm{x}$ & $\mathrm{x}$ \\
\hline & PT2020-Incentive to Innovation-lag5 & + & + \\
\hline \multirow{3}{*}{ Governmental Support } & Health expenses & $\mathrm{x}$ & $\mathrm{x}$ \\
\hline & Education expenses & $x$ & + \\
\hline & Minimum wage & $x$ & $\mathrm{x}$ \\
\hline
\end{tabular}

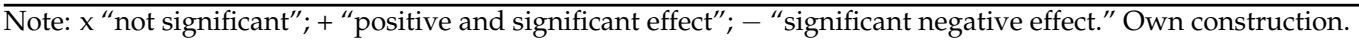

In general, tax incentives are good drivers of profitability for Portuguese SMEs. The impact of financial incentives has some inconsistencies. Tax incentives are easier to obtain for companies' managers and are used annually upon accounts presentation, considering 
that some criteria have been complied. In this case, the annual tax burden is reduced by a tax credit, and the benefit is immediately considered on results, as Cicchiello et al. [54] attest. Crespi et al. [55] uphold that government tax incentives increase firms' innovation efforts. Steshenko and Tikhonova [56] and Baghana and Mohnen [57] confirm tax incentives' effectiveness.

On the other hand, EU financial incentives are a long-term achievement subject to specific investment criteria, and the money received will only be considered a grant if specific goals are achieved in the long term, usually 3 to 4 years. The effects of the subsidy change upon the type of innovation investment that is subsidized, sector, and size of the firm [55].

The QREN incentives positively influence the ROA and negatively influence the ROE, probably due to accounting issues. On the other hand, Portugal 2020 incentives have a low relevance in the first years, increasing in the following years, contributing to sustainable performance. However, the R\&DT incentive does not show any significance. Regarding government incentives, only health expenditures have a positive impact on ROE.

\section{Conclusions}

Concerning tax variables, it should be noted that, in general, the results are significant for the profitability of SMEs since, when companies benefit from tax incentives, their profitability increases as a result of a reduction in the tax burden. However, it should be noted that the tax incentive for creating jobs only affects the ROA. Accordingly, the contribution of tax incentives is favorable to sustainable performance over the years.

As for the QREN financial incentives, they positively influenced the ROA and negatively influenced the ROE. However, the R\&DT incentive only shows significance in ROA. An explanation for these results may be associated with the economic and financial crisis that Portugal was experiencing in 2007 or the way that those grants are classified in accounting terms.

Regarding the Portugal 2020 incentive system, the results do not show a defined impact. Namely, the Incentive for Business R\&D is also not significant. This nonrelation is likely due to the absence of a sufficiently solid critical mass of accumulated knowledge from which these incentives determine profitability [58]. As for the Incentive for Qualification and Internationalization, the results are contradictory, with positive and negative impacts over the years on profitability. The country's economic situation could explain this, according to the work of [59], which notes that the home country conditions affect the internationalization-firm performance relationship, depending on the background ambiguity. As for the Incentive to Innovation, it reveals better results in the final year of analysis. The lagged effect of financial incentives weighted by the sub-prime crisis is explained by the different impacts that incentives produce on production systems and the internationalization of companies contributing to sustainability in the long term. It probably results from the unstable financial situation in which companies find themselves. According to Okafor et al. [60], in a crisis period, the pursuit of financial incentives for financially constrained firms might lead to competitiveness.

Finally, government support provided by the State, in general, does not determine the profitability of SMEs in Portugal, except for education expenditure, which shows significance in ROE.

Business profitability is conditioned by tax, financial, and government incentives. These constitute an important economic policy instrument for ensuring the long-term sustainability of businesses, although tax incentives can be a quick way to increase value.

This study is considered relevant for stakeholders, as it analyzes the drivers of ROA and ROE. Furthermore, based on these results, the managers/shareholders identify the incentives of most significant interest given the identified needs. The main limitation is associated with the geographic scope contemplated in the study and the difficulty in establishing terms of comparison with companies inserted in other institutional contexts, with other grant frameworks. Future work should extend its geographic scope to other 
countries, seeking to establish comparative analyses, use alternative indicators to measure performance, and incorporate new drivers of profitability.

The COVID-19 pandemic effect is not approached in this paper due to the coverage years (2010-2019). However, recent studies examined the combined individual government response measures, such as lockdown, health, and financial support, and concluded that those actions did not demonstrate their impact on reducing market risk performance $[61,62]$.

\section{Limitations and Future Research}

As far as our knowledge is concerned, it is well-known in academia that tax or financial incentives influence company performance. However, the literature concerning their impact on SMEs' performance is scarce, and literature on dealing with individual incentive measures is even scarcer. This paper fills that gap. Nevertheless, according to several individual incentives measures, a global SMEs study should be conducted for Europe and SMEs context. With this entire work, leaders and government measures will have a comprehensive tool for selecting and managing incentive instruments and determining how long those incentives take to affect companies' performance. The new future European guidelines for the period of 2019-2024 are (i) a European Green Deal, (ii) A Europe fit for the digital age, (iii) an economy that works for people, (iv) a stronger Europe in the world, (v) promoting our European way of life, and (vi) a new push for European democracy [63]. New studies should consider the effect of the use by governments and companies of the incentives related to those priorities, measuring those implications on SMEs' performance and sustainability.

Author Contributions: Conceptualization, S.P., P.R. and A.P.; methodology, S.P., P.R. and A.P.; software, S.P., P.R. and A.P.; validation, S.P., P.R., A.P. and J.L.A.; formal analysis, S.P., P.R., A.P. and J.L.A.; investigation, S.P., P.R. and A.P.; resources, S.P., P.R. and A.P.; data curation, S.P., P.R. and A.P.; writing-original draft preparation, S.P., P.R., A.P. and J.L.A.; writing-review and editing, S.P., P.R., A.P. and J.L.A.; visualization, S.P., P.R., A.P. and J.L.A.; supervision, P.R., A.P. and J.L.A.; project administration, P.R., A.P. and J.L.A.; funding acquisition, J.L.A. All authors have read and agreed to the published version of the manuscript.

Funding: This work is funded by National Funds through the FCT_-Foundation for Science and Technology, I.P., within the scope of the project Ref ${ }^{a}$ UIDB/05583/2020. Furthermore, we would like to thank the Research Centre in Digital Services (CISeD) and the Polytechnic of Viseu for their support.

Institutional Review Board Statement: Not applicable.

Informed Consent Statement: Not applicable.

Data Availability Statement: Restricted data: SABI database. The data presented in this study are openly available in: https://info.portaldasfinancas.gov.pt/pt/dgci/divulgacao/Area_Beneficios_ Fiscais/Listas_de_contribuintes_com_beneficios_fiscais/Paginas/Contribuintes_com_beneficios_fiscais_ 2020.aspx (accessed on 29 January 2021). http:/ / www.pofc.qren.pt/Areas-do-Compete/Incentivos-asEmpresas / Projectos-Aprovados-QREN?area=2\&regiao=102\&Search=y (accessed on 29 January 2021). https: / / www.compete2020.gov.pt/Projetos/Projetos (accessed on 29 January 2021). www.pordata.pt (accessed on 29 January 2021).

Acknowledgments: This work is funded by National Funds through the FCT-Foundation for Science and Technology, I.P., within the scope of the project Ref ${ }^{a}$ UIDB/05583/2020. Furthermore, we would like to thank the Research Centre in Digital Services (CISeD) and the Polytechnic of Viseu for their support.

Conflicts of Interest: The authors declare no conflict of interest.

\section{References}

1. Noja, G.G.; Cristea, M.; Jurcut, C.N.; Buglea, A.; Lala Popa, I. Management Financial Incentives and Firm Performance in a Sustainable Development Framework: Empirical Evidence from European Companies. Sustainability 2020, 12, 7247. [CrossRef]

2. Zhang, Y.H.; Wang, Y. The Impact of Government Incentive on the Two Competing Supply Chains under the Perspective of Corporation Social Responsibility: A Case Study of Photovoltaic Industry. J. Clean. Prod. 2017, 154, 102-113. [CrossRef] 
3. Ravšelj, D.; Aristovnik, A. The Impact of Private Research and Development Expenditures and Tax Incentives on Sustainable Corporate Growth in Selected OECD Countries. Sustainability 2018, 10, 2304. [CrossRef]

4. Carvalho, A. Subsídios ao Investimento na Rentabilidade das Empresas-O Caso dos SI Inovação. Master's Thesis, Faculdade de Economia da Universidade do Porto, Porto, Portugal, 2014.

5. Baganha, M.; Ribeiro, J.; Pires, S. O Sector da Saúde em Portugal. Funcionamento do Sistema e Caracterização Sócio-Profissional; Centro de Estudos Sociais: Coimbra, Portugal, 2002; Volume 33.

6. Antunes, M.G.; Mucharreira, P.R. Os Efeitos Das Variáveis Macroeconómicas No Desempenho Das Organizações: Evidência Das Pequenas e Médias Empresas Em Portugal. Contab. Gestão 2015, 17, 115-143.

7. Taghizadeh-Hesary, F.; Yoshino, N.; Rasoulinezhad, E. Unconventional Monetary Policy and Income Disparity in an Aging Society. J. Econ. Policy Reform 2021, 1-20. [CrossRef]

8. Jin, Z.; Shang, Y.; Xu, J. The Impact of Government Subsidies on Private R\&D and Firm Performance: Does Ownership Matter in China's Manufacturing Industry? Sustainability 2018, 10, 2205. [CrossRef]

9. Zúñiga-Vicente, J.Á.; Alonso-Borrego, C.; Forcadell, F.J.; Galán, J.I. Assessing the effect of public subsides on firm R\&D investment: A survey. J. Econ. Surv. 2014, 28, 36-67. [CrossRef]

10. Mao, R.; Xu, H.; Wu, W.; Li, J.; Li, Y.; Lu, M. Overcoming the Challenge of Variety: Big Data Abstraction, the next Evolution of Data Management for AAL Communication Systems. IEEE Commun. Mag. 2015, 53, 42-47. [CrossRef]

11. Wallsten, S. The Effects of Government-Industry R\&D Programs on Private R\&D: The Case of the Small Business Innovation Research Program. RAND J. Econ. 2000, 31, 82-100. [CrossRef]

12. Menezes, H.C. Princípios de Gestão Financeira, 11th ed.; Editorial Presença: Lisbon, Portugal, 2008.

13. Basu, S. Investment Performance of Common Stocks in Relation to Their Price-Earnings Ratios: A Test of the Efficient Market Hypothesis. J. Financ. 1977, 32, 663-682. [CrossRef]

14. Martín-Albo, J.; Núñiez, J.L.; Navarro, J.G.; Grijalvo, F. The Rosenberg Self-Esteem Scale: Translation and Validation in University Students. Span. J. Psychol. 2007, 10, 458-467. [CrossRef] [PubMed]

15. Berger, A.; Humphrey, D.B. Efficiency of Financial Institutions: International Survey and Directions for Future Research. Eur. J. Oper. Res. 1997, 98, 175-212. [CrossRef]

16. Nogueira Reis, P.M.; Gomes Augusto, M. Determinants Of Firm Terminal Value: The Perspective Of North American And European Financial Analysts. Int. Bus. Econ. Res. J. 2014, 13, 793-808. [CrossRef]

17. Srinivasan, P. Determinants of Equity Share Prices in India: A Panel Data Approach. Rom. Econ. J. 2012, 15, $205-228$.

18. Khan, S.H. Determinants of Share Price Movements in Bangladesh—Dividends and Retained Earnings. Master's Thesis, Blekinge Institute of Technology, Karlshamn, Sweden, 2009.

19. Bondt, G.D. Determinants of Stock Prices: New International Evidence. J. Portf. Manag. 2008, 34, 81-92. [CrossRef]

20. Sunde, T.; Sanderson, A. A Review of the Determinants of Share Prices. J. Soc. Sci. 2009, 5, 188-192. [CrossRef]

21. Nisa, M.U.; Nishat, M. The Determinants of Stock Prices in Pakistan. Asian Econ. Financ. Rev. 2011, 1, $276-291$.

22. Somoye, R.O.C.; Akintoye, I.; Oseni, J.E. Determinants of Equity Prices in the Stock Markets. Int. Res. J. Financ. Econ. 2009, 30, 177-189.

23. Serrasqueiro, Z. Growth and Profitability in Portuguese Companies: A Dynamic Panel Data Approach. Amfiteatru Econ. 2009, 11, 265-279.

24. Magnan, M.; St-Onge, S. The Impact of Profit Sharing on the Performance of Financial Services Firms*. J. Manag. Stud. 2005, 42, 761-791. [CrossRef]

25. Muhmad, S.N.; Muhamad, R. Sustainable Business Practices and Financial Performance during Pre- and Post-SDG Adoption Periods: A Systematic Review. J. Sustain. Financ. Investig. 2021, 11, 291-309. [CrossRef]

26. Husain, T.; Sarwani; Sunardi, N.; Lisdawati. Firm's Value Prediction Based on Profitability Ratios and Dividend Policy. Financ. Econ. Rev. 2020, 2, 13-26. [CrossRef]

27. Rivard, P. Growth or Profitability First? The Case of Small and Medium-Sized Enterprises in Canada Small Business Branch Research and Analysis Directorate; Government of Canada: Ottawa, ON, Canada, 2014; ISBN 9781100247366.

28. Brealey, R.; Myers, S.; Allen, F. Principles of Corporate Finance, 13th ed.; McGraw-Hill Education: New York, NY, USA, 2018; pp. 765-785.

29. Abdul Aziz, A.; Abdul, R. The Relationship between Solvency Ratios and Profitability Ratios: Analytical Study in Food Industrial Companies Listed in Amman Bursa. Int. J. Econ. Financ. Issues 2017, 7, 86-93.

30. Bagina, R.W. Assessing the Financial Statement (Ratios) of Anglogold Ashanti Limited, Ghana. Asian J. Econ. Bus. Account. 2020, 14, 45-55. [CrossRef]

31. Neves, J.C. Análise e Relato Financeiro, Uma Visão Integrada de Gestão; Texto Editora: Lisbon, Portugal, 2012.

32. Guerra, M.S.S. Taxa Efetiva de Imposto e Os Incentivos Fiscais: Evidência Empírica Sobre Portugal. Master's Thesis, Faculdade de Economia da Universidade do Porto, Porto, Portugal, 2019.

33. Huang, C.-H.; Hou, T.C.-T. Innovation, Research and Development, and Firm Profitability in Taiwan: Causality and Determinants. Int. Rev. Econ. Financ. 2019, 59, 385-394. [CrossRef]

34. Makeeva, E.; Murashkina, I.; Mikhaleva, I. The Impact of R\&D Tax Incentive Programs on the Performance of Innovative Companies. Foresight 2019, 21, 545-562. [CrossRef] 
35. Cerqua, A.; Pellegrini, G. Do Subsidies to Private Capital Boost Firms' Growth? A Multiple Regression Discontinuity Design Approach. J. Public Econ. 2014, 109, 114-126. [CrossRef]

36. Praça, A.C.O. Determinantes de Corporate Tax Planning: O Caso Português. Master's Thesis, Faculdade de Economia da Universidade do Porto, Porto, Portugal, May 2018.

37. Mills, L.; Newberry, K.J. Do Foreign Multinationals' Tax Incentives Influence Their U.S. Income Reporting and Debt Policy? Natl. Tax J. 2004, 57, 89-107. [CrossRef]

38. Carvalho, A.G. Governança Corporativa No Brasil Em Perspectiva. RAUSP Manag. J. 2002, 37, $19-32$.

39. Monteiro, V.F.M. Estudo Multi-Caso: PME do Setor das Tecnologias de Informação, Comunicação e Eletrónica: Portugal 2020. Master's Thesis, Instituto Politécnico de Setúbal, Setúbal, Portugal, 2016.

40. Lapão, L.V.; Pisco, L. A Reforma Da Atenção Primária à Saúde Em Portugal, 2005-2018: O Futuro e Os Desafios Da Maturidade. Cad. Saude Publica 2019, 35, 1-12. [CrossRef]

41. The Lancet. Bringing Frailty into All Realms of Medicine. Lancet 2019, 394, 1298. [CrossRef]

42. Jaya, T.E.; Septiarini, T.; Arafat, Y. Educational Background of the Board of Commissioners, Leverage, Profitability and Voluntary Disclosure. Rev. Integr. Bus. Econ. Res. 2016, 5, 260-271.

43. Draca, M.; Machin, S.; Van Reenen, J. Minimum Wages and Firm Profitability. Am. Econ. J. Appl. Econ. 2011, 3, 129-151. [CrossRef]

44. Osoro, C.; Ogeto, W. Macro Economic Fluctuations Effects on the Financial Performance of Listed Manufacturing Firms in Kenya. Int. J. Soc. Sci. 2014, 21, 26-40.

45. Varela, R.C.; Pereira, L.B. Restruturação Produtiva Na Europa. Rev. Katálysis 2018, 21, 157-167. [CrossRef]

46. Instituto Nacional de Estatística. Empresas em Portugal-2018; Estatisticas Oficiais: Lisboa, Portugal, 2020; Volume 53, ISBN 9788578110796.

47. Mayende, S. The Effects of Tax Incentives on Firm Performance: Evidence from Uganda. J. Polit. Law 2013, 6, 95-107. [CrossRef]

48. Mateus, A. Estudo de Avaliação Intercalar Do Programa Operacional Fatores de Competitividade. Compete 2013, 499, 70-84.

49. García-Manjón, J.V.; Romero-Merino, M.E. Research, Development, and Firm Growth. Empirical Evidence from European Top R\&D Spending Firms. Res. Policy 2012, 41, 1084-1092.

50. Tirole, J. Economics for the Common Good; Princeton University Press: New Jersey, NJ, USA, 2019; ISBN 97800691192253.

51. Gonçalves, V.d.C.; Miranda Sarmento, J.; Rodrigues, R. Aftermath of the Sovereign Debt Crisis, the New Challenges to Competitiveness in Portugal. Econ. Res. Istraz 2021, 34, 998-1012. [CrossRef]

52. Bannò, M.; Piscitello, L.; Amorim varum, C. The Impact of Public Support on SMEs' Outward FDI: Evidence from Italy*. J. Small Bus. Manag. 2014, 52, 22-38. [CrossRef]

53. Roper, S.; Hewitt-Dundas, N. Grant Assistance and Small Firm Development in Northern Ireland and the Republic of Ireland. Scott. J. Polit. Econ. 2001, 48, 99-117. [CrossRef]

54. Cicchiello, A.F.; Battaglia, F.; Monferrà, S. Crowdfunding Tax Incentives in Europe: A Comparative Analysis. Eur. J. Financ. 2019, 25, 1856-1882. [CrossRef]

55. Crespi, G.; Giuliodori, D.; Giuliodori, R.; Rodriguez, A. The Effectiveness of Tax Incentives for R\&D+i in Developing Countries: The Case of Argentina. Res. Policy 2016, 45, 2023-2035. [CrossRef]

56. Steshenko, J.; Tikhonova, A. An Integral Approach to Evaluating the Effectiveness of Tax Incentives. J. Tax Reform 2018, 4, 157-173. [CrossRef]

57. Baghana, R.; Mohnen, P. Effectiveness of R\&D Tax Incentives in Small and Large Enterprises in Québec. Small Bus. Econ. 2009, 33, 91-107. [CrossRef]

58. Trachuk, A.; Linder, N. Innovation and Performance: An Empirical Study of Russian Industrial Companies. Int. J. Innov. Technol. Manag. 2018, 15, 1850027. [CrossRef]

59. Cuervo-Cazurra, A.; Ciravegna, L.; Melgarejo, M.; Lopez, L. Home Country Uncertainty and the Internationalization-Performance Relationship: Building an Uncertainty Management Capability. J. World Bus. 2017, 53, 209-221. [CrossRef]

60. Okafor, L.E.; Bhattacharya, M.; Apergis, N. Bank Credit, Public Financial Incentives, Tax Financial Incentives and Export Performance during the Global Financial Crisis. World Econ. 2020, 43, 114-145. [CrossRef]

61. Baig, A.S.; Butt, H.A.; Haroon, O.; Rizvi, S.A.R. Deaths, Panic, Lockdowns and US Equity Markets: The Case of COVID-19 Pandemic. Financ. Res. Lett. 2021, 38, 101701. [CrossRef]

62. Reis, P.M.N.; Pinho, C. COVID-19 Surprise Effect and Government Response Measures on the Influence on Asset Pricing Risk among European Travel and Airline Sectors. In Pandemics and Travel; Seabra, C., Paiva, O., Silva, C., Abrantes, J.L., Eds.; Emerald Publishing: Bingley, UK, 2021; pp. 121-139. ISBN 978-1-80071-071-9.

63. The European Commission. The European Commission's Priorities. Available online: https://ec.europa.eu/info/strategy/ priorities-2019-2024_en (accessed on 18 October 2021). 